\author{
Farkas AnetT \\ Eszterházy Károly Egyetem \\ farkas.anett@uni-eszterhazy.hu
}

\title{
A DIGITÁLIS KÖZEGBEN TÖRTÉNÖ KOMMUNIKÁCIÓS KOMPETENCIAFEJLESZTÉS HATÉKONYSÁGA
}

\section{Bevezetés}

A XXI. században a magyar középiskolai oktatás is orientálódik a digitális közegben történő tanulási környezet felé. A technikai fejlődés következtében a tudás megszerzésének egy újabb módjára ad lehetőséget a diákok számára. Az egyre inkább virtuálissá váló tanulási környezet új kihívásokat, megoldandó kérdéseket, problémákat állít az oktatástervező szakemberek és a pedagógusok felé.

\section{Szakirodalmi háttér}

A diákok már nem az iskolában szerzik meg tudásuk jelentős részét, így a tanár szerepe is megváltozik. A tartalmi tudásról egyre inkább a készségek, kompetenciák fejlesztésére helyeződik a hangsúly (Z. Karvalics 1997).

Komenczi Bertalan (2009) az elektronikus tanulási környezet fogalmát gyűjtőfogalomként használja: „olyan tanulási környezeteket jelent, ahol a tanítás és tanulás feltételrendszerének kialakításánál meghatározó szerepe van az elektronikus információ- és kommunikációtechnikai eszközöknek" (Komenczi 2009: 114).

A digitális tananyagok beilleszthetők a tanórák menetébe, továbbá hozzájárulhatnak az otthoni (önálló) tanuláshoz is. Iskolai megjelenésük a hagyományos tanítási-tanulási környezet átstrukturálódási folyamatát erősíti (vö. Jánk 2016). „A számítógéppel segített tanítás és tanulás legfontosabb célja egy olyan új képességrendszer kialakítása, amely a tudásalapú társadalomban való működést megkönnyíti, s a munka és szabadidő kultúráját teljesebbé teszi” (Kárpáti 2002: 5).

„Ahhoz, hogy a diákok a virtuális környezetben aktív, konstruktív és kollaboratív tanulással új tudásra tegyenek szert, mindenekelőtt egy olyan jó projekt, feladat szükséges, melyet a tanulók meg tudnak valósítani a virtuális világbeli környezetben. Ilyen projekt kitalálása a tanár számára nem könnyű feladat, hiszen át kell gondolnia, gyakran ki kell próbálnia a megvalósíthatóságát a virtuális környezetben. A legtöbb esetben azonban a tanár fáradozása megtérül, hiszen a projekt segítségével a diákok játékos módon, konstruktív és kollaboratív tanulással új tudásra tesznek szert" (Racsko-Varga 2017: 152). 
Faragó Boglárka (2015) tanulmányában leírja, hogy a digitális tartalmakat a tanulókhoz kell igazítani. A tanulócentrikus megközelítést az innovációk tanulási folyamatot támogató felhasználási viszonylatban használja (Faragó 2015).

A hagyományos információátadási formákat egyre inkább kiegészíti a tevékenységközpontú, tanulói interaktivitást előfeltételező megközelítés. Lanszki Anita (2015) erre jó példaként említi a Stanford Egyetemen kidolgozott és tesztelt Scenario-Based Learning (SBL) módszert, amely az aktív, gyakorlatorientált tanulói problémamegoldást helyezi a középpontba az online kooperáció lehetőségeivel (Lanszki 2015).

A gyakorlati eredmények által megállapítható továbbá, hogy a blended learning, vagyis a vegyes oktatás a legsikeresebb, amikor e-learning eszközökkel ötvözik a hagyományos oktatást. Bár kezdetben több terhet jelent az e-learning használata, később megtérül az oktató számára (Benedek et al. 2012).

A kompetenciafejlesztés fontossága a pedagógiai munka során manapság nélkülözhetetlen. A kompetencia egy összetett és több meghatározásban is létező fogalom, amely leginkább úgy határolható körül, hogy különbözö, de egymással szorosan összefüggő komponensek alkotják, melyek az egyén személyiségével és környezetével állnak kölcsönhatásban.

Nagy József (2010) az alábbi fogalommeghatározást alkotta: „A kompetencia olyan pszichikus komponensrendszer, amelynek 1) közvetlen felsőbb komponensrendszere a személyiség, és amelynek alsóbb pszichikus komponensrendszerei: 2) a motívumrendszer és 3) a tudásrendszer, valamint 4) az öröklött komponensek és 5) a tanult komponensek." (Nagy 2010: 8.)

Szőke-Milinte Enikő (2012) a kommunikáció irányából közelítette meg a fogalmat. Nagy József (2000) mintájára alapozva azt emeli ki, hogy a személyiség egésze meg tud nyilvánulni a kommunikációs kompetenciában. Komplex komponenskészletnek nevezi, mert a kognitív, a szociális, a személyes és a speciális kompetenciák alapját képezi, továbbá a motivációs (hajlam), képesség (készség) és ismeretbeli (tudás) összetevőből szerveződik. (Szőke-Milinte 2012).

Az, hogy a kompetenciafejlesztést kiemelkedő feladatnak tekintjük, összhangban van a 2012-ben elfogadott Nemzeti alaptanterv koncepciójával is. Eszerint az anyanyelvi kommunikáció magában foglalja a fogalmak, gondolatok, érzések, tények, vélemények kifejezését és értelmezését, megörzését és közvetítését szóban és írásban (hallott és olvasott szöveg értése, szövegalkotás szóban és írásban). Továbbá tartalmazza a helyes, öntudatos és alkotó nyelvhasználatot az oktatásban és képzésben, a társadalmi és kulturális tevékenységek során, a családi és a társas életben, a munkában és a szabadidős tevékenységekben, a társas valóság formálásában és a kognitív képességek fejlödéséhez is kapcsolódik. Megemlítendő, hogy mindez a 2020-ban kiadott Nemzeti alaptantervben csupán implicit formában jelenik meg, mivel az egyes kulcskompetenciák nem kerülnek kifejtésre a szövegben, nincsenek meghatározva az egy kompetenciák tartalmai (erről l. Jánk 2020). 
Feltétele a megfelelő szókincs, nyelvtan és az egyes nyelvi funkciók ismerete, melyhez hozzátartozik a szóbeli és írásbeli kapcsolattartás fó típusai, az irodalmi és nem irodalmi szövegek, a különböző nyelvi stílusok fő sajátosságai, valamint a kommunikáció változásai.

A 2017. május-júniusi érettségi vizsgaidőszaktól hatályos követelményrendszere szintén először a kompetenciákat határozza meg magyar nyelv és irodalomból, melyek között a szövegértés, írásbeli szövegalkotás, szóbeli szövegalkotás, beszéd és a fogalomhasználat szerepelnek középszinten.

\section{Kutatási előzmények, célok}

A kutatás a kommunikációs kompetenciafejlesztés területén, a digitális tananyagfejlesztésbe integrálható gyakorlatokat és megoldásokat, valamint módszertani és elméleti megközelítéseket alkalmazza. Az oktatástervezés területén pedig a már meglévő elméletekből és kutatásokból indul ki, figyelembe véve a tartalomfejlesztés módszertanát, felhasználva a meglévő kutatási eredményeket a tananyagfejlesztés tervezése során.

A kutatás célja a digitális közegben történő kommunikációs kompetenciafejlesztés hatékonyságának vizsgálata volt. A Moodle felületén dolgoztam ki egy tevékenységközpontú digitális tananyagot a kommunikáció témakörén belül, a középiskolás gimnáziumi diákok számára.

\section{Mintavétel, módszer}

A kutatás mintavétele az Egri Dobó István Gimnázium 11. évfolyamát tette ki, ami a 17-19 éves korcsoportot jelentette. A minta nem reprezentatív, pilot kutatásnak minősül. A digitális tananyag tesztelését három csoportba osztottam az alábbiak szerint:

Az első csoportba a gimnázium B osztálya került, akik a 28 főből 24-en adtak elemezhető, releváns válaszokat. Ez a csoport csak a digitális tananyaggal sajátította el az ismereteket.

A második csoportba a gimnázium $\mathrm{C}$ osztálya került, akik a 32 főből 27-en adtak elemezhető, releváns válaszokat. Ez a csoport a kombinált csoportot jelentette, mely a digitális tananyag mellett offline is kapott ismereteket.

A harmadik csoportba a gimnázium E osztálya került, akik a 30 fóből a 25-en adtak elemezhető, releváns válaszokat. Ök hagyományos tanórai képzésben részesültek, ők tették ki a kontrollcsoportot, akik nem kaptak digitális tananyagot.

Így összesen a 90 fós vizsgálati mintából 76 fós mintavétellel tudtam elvégezni a számomra rendelkezésre álló adatok elemzését. A hiányzó 14 fö közül többen is hiányoztak egyik vagy másik teszt megírásakor, illetve feltehetően érdektelenségből és/ vagy motiválatlanságból üresen adták be egyik vagy másik tesztet.

Ahhoz, hogy a digitális tananyag által végbement változásokat mérni tudjam, szükségesnek tartottam egy bemeneti és egy kimeneti teszt elkészítését. A tesztek összeállítása 
során arra törekedtem, hogy a NAT-ban is meghatározott kommunikációs készségek is azonosíthatók legyenek a mérőeszközben. Az alábbi táblázat a feladatok és a hozzájuk kapcsolható készségeket mutatja:

\begin{tabular}{|c|c|c|}
\hline A vizsgált készségek & Feladatrész & $\begin{array}{c}\text { Feladat(ok) } \\
\text { sorszáma }\end{array}$ \\
\hline $\begin{array}{c}\text { pontosítás, magyarázat, müfajok } \\
\text { felismerése }\end{array}$ & Műfaj felismerése és jellemzése & 1 \\
\hline $\begin{array}{c}\text { szókincs, szóhasználat, } \\
\text { megfogalmazás, magyarázat }\end{array}$ & Szavak értelmezése & 2 \\
\hline $\begin{array}{c}\text { verbális és nem verbális kommu- } \\
\text { nikációs helyzetelemzés/felismerés, } \\
\text { elméleti fogalmak gyakorlati } \\
\text { alkalmazása }\end{array}$ & $\begin{array}{c}\text { A kommunikációs tényezök } \\
\text { meghatározása } \\
\text { A kommunikációs típusok } \\
\text { meghatározása }\end{array}$ & $3,4,6$ \\
\hline $\begin{array}{c}\text { A szövegbe ágyazott kép nem } \\
\text { verbális kommunikációs elemzése }\end{array}$ & 5 \\
\hline $\begin{array}{c}\text { lényegkiemelés, tömörítés } \\
\text { szövegértés }\end{array}$ & $\begin{array}{c}\text { Szövegértés } \\
\text { megfogalmazás }\end{array}$ & 7 \\
\hline $\begin{array}{c}\text { ónfeltárás, megfogalmazás, } \\
\text { véleményformálást/állásfoglalás, } \\
\text { nyelvhasználat } \\
\text { önreflexió, válaszadási készség, } \\
\text { önfeltárás }\end{array}$ & $\begin{array}{c}\text { Érvelő fogalmazás készítése } \\
\text { Önismereti kérdések az olvasott } \\
\text { szöveg alapján }\end{array}$ & 8,9 \\
\hline
\end{tabular}

1. táblázat: A kommunikációs kompetencia mérőtesztjének strukturált változórendszere

\section{A digitális tananyag felépítése}

A tananyag felépítése a középiskolás diákok NAT-ban meghatározott követelményrendszereire épül, mely magában foglalja a 9-11. évfolyam nyelvtan tantárgy kommunikációs tartalmának főbb elemeit. Ezáltal a különböző évfolyamokban is alkalmazható, mivel integrált tananyagról van szó, akár különálló kommunikáció tantárgyként is megállja a helyét.

A digitális kurzus három témakörre épül, mely négy leckére tagolódik. Az első lecke a kommunikáció alapfogalmait, tényezőit, funkcióit és csoportosítási lehetőségeit foglalja magában. A második lecke a metakommunikáció és a nonverbális kommunikáció 
csatornáira épül. A harmadik lecke a hagyományos média, míg a negyedik lecke az újmédia fogalomkörét, csoportosítási lehetőségét és hatásait járja körül. A leckék mindegyike tartalmaz kiegészítő videótartalmat, illetve összegzést és egy rövidebb vázlatot. Minden lecke végén található érvelő fogalmazást készítő és szövegértési feladat is.

A feladatok a bemeneti és kimeneti teszthez hasonlóan, a már említett kommunikációs kompetencia komponenseire épülnek. Található közöttük a verbális és nem verbális kommunikációs helyzetek elemzésének készségére épülő kép- és videóelemzési, valamint szövegértési, érvelési, vázlatkészítési és műfaj felismerésére vonatkozó, sőt utóbbinál a müfajt kipróbáló, kreatív szövegalkotási feladat is. A NAT által elvárt tantárgyköziség elvére építve a tananyag számos kapcsolódási pontot tartalmaz az alábbi tantárgyakkal: biológia, történelem, földrajz, irodalom, etika, mozgóképkultúra és médiaismeret, informatika.

\section{Eredmények}

A tananyag eredményességét bementi és kimeneti tesztekkel hasonlítottam össze a vizsgált osztályok között.

Az első számú hipotézis (H1) szerint a digitális tananyaggal tanuló (csak elektronikus tananyagot használó, és az offline és elektronikus tananyagot használó) csoportok kommunikációs kompetenciája fejlődő tendenciát mutat. Ezt az eredményt a $\mathrm{B}(\mathrm{N}=24)$ és a $C(N=27)$ osztályok kimeneti méréseinek összeredményének összehasonlításával kaphatjuk meg. A kétmintás t-próba alapján megállapítható, hogy a két csoport átlaga szignifikánsan különbözik egymástól $\left(\mathrm{t}^{\prime \prime}=-2,01 \mathrm{df}=49 \mathrm{p}=0,05\right)$. A C, azaz a kombinált módszert használó osztály $(\mathrm{N}=27)$ teszten elért összpontszámának átlaga 64,07 (szórás 12,28), míg a csupán elektronikus tananyagot használóké 56,71 (szórás 13,87), tehát a teljesítménykülönbség jelentős. A csak digitális tananyagot használó és az offline és elektronikus tananyagot használó csoportok kommunikációs kompetenciája fejlődő tendenciát mutat, az első számú hipotézis beigazolódott az eredmények alapján. Tehát a tevékenységközpontú digitális tananyag eredményes és hatékony eszköz lehet a kommunikációs kompetenciafejlesztés területén a középiskolás diákok számára.

Ezt támasztják alá azok az adatok is, melyek az osztályok bemeneti és kimeneti tesztekben szereplő részfeladatok eredményeinek összehasonlítását vizsgálták. A kiválasztott részfeladatok közül a verbális és nem verbális kommunikációs helyzetelemzési készség, mely az elméleti tudás gyakorlati alkalmazásának készségével állt együtt három feladatban is (3. feladat, 4. feladat, 6. feladat), azt mutatja, hogy azok a vizsgált osztályok, akik digitális tananyagot használtak, a bementi mérések átlageredményéhez képest jelentôs fejlödésen estek át. Tehát a digitális tananyag jól alkalmazható a kommunikációs kompetencia egyes készségeinek fejlődésére. Jelen esetben képes fejleszteni a verbális és nem verbális kommunikációs helyzetelemzési készséget, illetve az elméleti tudás gyakorlati alkalmazásának készségét. 
Ehhez hasonló eredményt mutat a vizsgált osztályok érvelési készségének vizsgálata (9. feladat) is, mely magában foglalja a kritikai gondolkodásmód, önfeltárás, megfogalmazás, véleményformálást/állásfoglalás, nyelvhasználat, önreflexió készségeit. Ezek a készségek szintén egyértelmű fejlődő tendenciát mutattak a digitális tananyagot használó osztályok bementi méréseinek átlageredményéhez képest. Tehát a digitális tananyag jól alkalmazható a Nemzeti alaptantervben, illetve az érettségi követelmények által meghatározott érvelési készség fejlesztését tekintve.

Ugyanakkor a kontrollcsoport eredményei azt támasztják alá, hogy a csak hagyományosan, offline módon tanuló diákokhoz képest a tevékenységközpontú digitális tananyagot használó diákok jobb eredményeket értek el a kommunikációs kompetenciafejlesztés és az ahhoz tartozó egyes készségek tekintetében. Tehát a kontrollcsoport és a digitális tananyagot használó diákok kommunikációs készségfejlődése között jelentős különbségek vannak.

A vázlatkészítés (lényegkiemelés és tömörítés készségének) elsajátításában azonban nem voltak meghatározó különbségek a bemeneti és a kimeneti teszteken elért eredmények között, egyik csoportnál sem. Az a megállapításom, hogy 11. évfolyamra a diákok már eljutottak arra a képességszintre, hogy megfelelően tudják ezeket a készségeket alkalmazni. Úgy vélem, hogy ennek a kommunikációs készségnek főként a belépő, 9. évfolyamon lenne összefüggést is mutató eredménye.

A második számú (H2) hipotézis a kommunikációs tényezők meghatározására vonatkozott. Előfeltevésem szerint kombinált csoport javára jelentős teljesítménykülönbség mutatkozik a záróteszt eredményében. Ezt a kimeneti teszt harmadik feladatából tudjuk megnézni, mely a kommunikációs tényezők meghatározását tartalmazta, ami a diákok kommunikációs helyzetelemzési készségének, valamint az elméleti fogalmak gyakorlati szintű alkalmazásának készségét jelentette. Ebben a feladatban maximálisan 8 pontot érhettek el a diákok.

A kétmintás t-próba alapján megállapítható, hogy a két csoport átlaga szignifikánsan különbözik egymástól ( $\left.\mathrm{t}^{\prime}=-2,50 \mathrm{df}=49 \mathrm{p}=0,016\right)$. A C, azaz a kombinált módszert használó osztály $(\mathrm{N}=27)$ a feladatban elért pontszámának átlaga 7,04 (szórás 1,60), míg a csupán elektronikus tananyagot használóké 5,79 (szórás 1,96). Tehát a kombinált módszerrel tanult csoport eredménye jelentős különbséget mutat a kommunikációs tényezők meghatározását tekintve.

A harmadik számú (H3) hipotézis szerint a vizsgált csoportok között a kommunikációs típusok elsajátításában jelentős teljesítménykülönbség mutatkozik a kombinált csoport javára, a záróteszt eredményében. Ezt a kimeneti teszt negyedik feladatából tudjuk megnézni, mely a kommunikációs típusok meghatározását tartalmazta, ami a diákok kommunikációs helyzetelemzési készségének, valamint az elméleti fogalmak gyakorlati szintű alkalmazásának készségét jelentette. A Welch-féle d-próba eredményei $(\mathrm{t}=-1,63 \mathrm{szf}=43,84 \mathrm{p}=0,11)$ alapján azt mondhatjuk, hogy nem szignifikáns a különbség a $B$ osztály $(N=24)$ és a $C$ osztály $(N=27)$ között. Tehát 
a kommunikációs típusok elsajátításában, a csoportosítási lehetőségek megértésében és alkalmazásában a csak online és a blended learning formában tanuló diákok teljesítményében nincs különbség.

\section{Tapasztalatok}

A kutatás lebonyolítása során számos szóbeli és írásbeli (Facebook- és Moodle-üzenet) visszajelzést (kérdéseket és véleményeket) kaptam a tananyagot használó diákoktól a tananyag felépítését, feladatait tekintve. Mivel ezek a visszacsatolások nem képezték a kutatás részét, ezért tapasztalatként számolok be erről.

A csak digitális tananyagot használó osztálynál tapasztaltam az egyéni haladási irányt. Többen is kérdezték, hogy gondot okoz-e, ha nem sorrendben veszik át a leckéket és a feladatokat, hanem ahogyan éppen érdeklödésük, hangulatuk engedi. Támogattam őket abban, hogy tetszőleges sorrendben, saját tempójukban haladjanak. Azt viszont sajnos nem volt lehetőségem mérni, hogy a saját haladási útvonalukat használt tanulók eredményesebbek voltak-e a tananyag sorendjét betartókkal szemben.

A problémákat sokszor az jelentette, hogy a diákok nem tudtak regisztrálni az oldalra, illetve nem látták át a feladatok elkészítésének felületét. Ezt azzal próbáltam orvosolni, hogy készítettem képernyőképmentéseket a regisztráció és a kurzusbeiratkozás lépéseiről, amit megosztottam a diákok közös Facebook-csoportjában. Illetve a visszajelzések alapján menet közben is javítottam és egyértelműsítettem a feladatokat, valamint az online üzenetváltások során bárki kérhetett segítséget.

Az önszabályozó tanulás aspektusából megállapítható néhány diák esetében, hogy nem volt hatékony a tananyag a belső motiváció kialakításában. A gyengébben teljesítők és alulmotiváltak kevésbé voltak képesek a források kritikai elemzésére, az önálló keresésre, továbbá válaszaik sem voltak kellően kidolgozttak.

Azt feltételeztem a 11. évfolyamos diákokról, hogy már képesek érvelő fogalmazás elkészítésére. Azonban a leckék feladatainak kitöltése közben egyre többen kerestek személyesen vagy online azzal a kérdéssel, hogy hogyan kell érvelő fogalmazást írni, vagy hogyan kell egy kép alapján nonverbális kommunikációs jelzéseket elemezni. Mindebből arra lehet következtetni, hogy a személyes oktatási környezet kialakítása fontos, illetve fejlesztésre szorulnak az önálló tanulásra való képességek is, a tanároknak a tananyag tanításakor figyelmet kell ezekre a felmerülő helyzetekre is gyors, a tanulók számára hatékony megoldást találni.

További tényezőként merült fel, hogy a vizsgált osztályok közül az E osztály, azaz a kontrollcsoport bemeneti teszten elért átlageredményeik nem szignfikánsan, de jobbak voltak a többi osztályokéhoz képest, náluk mutatható ki a legkevésbé a fejlődés. Ennek valószínúleg a motiváció állhatott a hátterében, hiszen a kimeneti teszt megírását láthatóan nem vették komolyan, siettek a megoldással. Tapasztalataim szerint a másik két osztályt az elektronikus tartalmakkal és a digitális tananyaggal jobban be 
lehetett vonni az oktatási munkába, együttműködőbbek voltak, láthatóan az újdonság erejével hatott számukra a téma ilyen irányú feldolgozása.

A diákokkal való beszélgetések során megtudtam, hogy tanáraik ritkán alkalmaznak IKT-eszközöket a tanórán, nagyrészt frontálisan oktatnak, és gyakran a tanár személyisége jelenti a motivációs faktort számukra. Hiába rendelkezik az iskola okostáblákkal és jól felszerelt számítógépes tantermekkel, megfelelő továbbképzések hiányában sokszor nem is hallottak az új technológiai megoldásokról, vagy hiába szeretnék azokat alkalmazni, nem tudják megfelelően használni az eszközöket, programokat és alkalmazásokat. Az a benyomásom, hogy a tanároknak minél több módszertani továbbképzésre és gyakorlati útmutatókra, bevált és alkalmazható példákra volna szükségük ahhoz, hogy hatékonyan tudják integrálni az új megoldásokat.

\section{8. Összegzés, kitekintés}

A kutatás aktualitását az a tendencia adja, hogy a virtuálissá váló, integrált tanulási környezet irányába törekvő elmozdulás új kihívásokat, megoldandó kérdéseket állít az oktatástervező szakemberek és a pedagógusok felé. Többek között arra a kérdésre ad választ, hogy fejleszthetők-e elektronikusan a kommunikációs kompetenciák, és ha igen, akkor hogyan és milyen módon lehet az eredményességet mérni.

Ahhoz, hogy egy digitális tananyag minél produktívabb és hatékonyabb legyen a kompetenciafejlesztés szempontjából, az oktatás súlypontjába a gyakorlatorientált, tanulói problémamegoldást központba helyező irányelvre van szükség. Az IKT-eszközök egyre inkább a pedagógiai célok használata alá rendelődnek. A kutatásokból az is kiderült, hogy a blended learning megoldási forma a leginkább hatékony.

A diákok összpontszámának átlageredményét összevetve ugyanis azt az eredményt kaptuk, hogy a csak digitális tananyagot és az offline és elektronikus tananyagot használó csoportok kommunikációs kompetenciája fejlődő tendenciát mutat, az első számú hipotézis beigazolódott az eredmények alapján. Tehát a tevékenységközpontú digitális tananyag eredményes és hatékony eszköz lehet a kommunikációs kompetenciafejlesztés területén a középiskolás diákok számára.

A bemeneti és kimeneti tesztek és a hozzájuk kapcsolódó háttéradatok nem mérték a diákok motivációját, amely jelentős változó lehet abban a tekintetben, hogy a motiváltabb diákok eredményesebben írhatják meg a teszteket, mint a kevésbé motiváltak. Úgy gondolom, hogy mindez akár osztályszinten is megjelenhet, így ha ezt a változót is lehetne számszerűsíteni, akkor az eredményeket is jelentősen befolyásolná. Egy későbbi kutatásban a motiváltság mentén is ki lehetne alakítani a csoportokat, hogy relevánsabb képet kapjunk a motivált, illetve a kevésbé motivált diákok közötti teszteredmények összevetésére.

Mivel a jelen munka pilot kutatásnak minősül, a digitális tananyagot, illetve a bemeneti és kimeneti teszteket más középiskolás évfolyamokon is meg szeretném vizsgálni 
a későbbiekben, illetve a mérhetőség szempontjából a jóságmutatók mentén is érdemesnek tartom statisztikai alávetésre is, hogy az eredmények még pontosabbak legyenek. A mérőeszköz-fejlesztés újabb fázisában érdemesnek tartom átdolgozni a bemeneti és kimeneti teszteket, további komponenseket, készségeket is vizsgálva, mint például a helyesírási, a kérdésfeltevési és válaszadási, vagy éppen a kreatív szövegalkotási készség. A teszteken túl pedig kérdőíves vagy interjú formában érdemes lenne feltárni a diákok tanulási motivációját, érdeklődési területeit, mely még hatékonyabb tananyag fejlesztését teszi lehetővé.

\section{Források}

100/1997. (VI. 13.) Kormányrendelet. Oktatási Hivatal honlapja. https://www.oktatas.hu/ pub_bin/dload/kozoktatas/erettsegi/vizsgakovetelmenyek2017/magyar_nyelv_es_irodalom_vk_2017.pdf (2018. 09. 06.)

\section{Irodalom}

Benedek András - Horváth Cz. János - Molnár György - Nagy Gábor Zsolt - Nyíri Kristóf - Szabó Erzsébet Mária - Tóth Péter - Verebics János 2012. Digitális pedagógia 2.0. Budapest: Typotext Kiadó.

Faragó Boglárka 2015. Tanulói aktivitás, aktív tanulás és tevékenység online környezetben. In: Lévai Dóra - Papp-Danka Adrienn (szerk.): Interaktív oktatásinformatika. Eger: EKF Líceum Kiadó. 19-30.

Jánk István 2016. Az Oktatáskutató és Fejlesztő Intézet digitális tananyagairól. Iskolakultuira 26/5: 131-138.

Jánk István 2020. A NAT 2020 és az anyanyelvi nevelés. Nyelv és Tudomány. https:// www.nyest.hu/hirek/nat-2020-es-az-anyanyelvi-neveles (2020. 01. 12.)

Z. Karvalics László 1997. Az információs írástudástól az internetig. Educatio 6/4: 681-698.

Kárpáti Andrea 2002. Informatikai "kereszttanterv” a számitógéppel segitett tanitás és tanulás új paradigmája. http://www.isze.hu/download/tananyagok/Tanulmany.pdf (2018. 09. 03.)

Komenczi Bertalan 2009. Elektronikus tanulási környezet. Budapest: Gondolat Kiadó.

Lanszki Anita 2015. A tanulói aktivitás szerepe a digitális történetmesélésben. In: Lévai Dóra - Papp-Danka Adrienn (szerk.): Interaktív oktatásinformatika. Eger: EKF Líceum Kiadó. 88-89.

Nagy József 2010. A személyiség kompetenciái és operációs rendszere. Iskolakultúra 20/7-8: 3-20.

NAT $2012=110 / 2012$. (VI. 4.) Korm. rendelet a Nemzeti alaptanterv kiadásáról, bevezetéséről és alkalmazásáról. Magyar Közlöny 66: 10635-10848. http://ofi.hu/sites/ default/files/attachments/mk_nat_20121.pdf (2018. 09. 06.) 
Racsko Réka - Varga Tamás 2017. IKT-innovációk, újmédiumok az oktatásban. In: Forgó Sándor (szerk.): Az információközvetitő szakmák újmédia-kompetenciái, az üjmédia lehetöségei. Eger: Líceum Kiadó. 143-160.

Szőke-Milinte Enikő 2012. A kommunikációs kompetencia a 2012-es NAT vitaanyagában. Anyanyelv-pedagógia 5/2. http://www.anyanyelv-pedagogia.hu/cikkek.php?id=380 (2018. 09. 27.)

Z. Karvalics László 1997. Az információs írástudástól az internetig. Educatio 6/4: 681-698. 